DOI: https://doi.org/10.31933/jimt.v2i4 Received: 19 Maret 2021, Revised: 25 Maret 2021, Publish: 4 April 2021

JIMT
JURNAL ILMU MANAJEMEN
TERAPAN

\title{
DETERMINASI PRESTASI KERJA DAN KEPUASAN KERJA: ETOS KERJA DAN DISIPLIN KERJA (SUATU KAJIAN STUDI LITERATUR MANAJEMEN SUMBERDAYA MANUSIA)
}

\author{
Dori Mittra Candana \\ Mahasiswa Program Doktor Manajemen, Universitas Putra Indonesia "YPTK" Padang, Indonesia, \\ dorimittra@upiyptk.ac.id
}

\begin{abstract}
Penelitian ini bertujuan untuk mengetahui Prestasi Kerja (Y1), Kepuasan Kerja (Y2), Etos Kerja (X1), Disiplin Kerja (X2), dalam study literature Manajemen Sumber Daya Manusia. Hasil dalam penelitian ini sebagai beriku;1. Etos Kerja berpengaruh positif dan signifikan terhadap Kepuasan Kerja 2. Disiplin Kerja berpengaruh positif dan signifikan terhadap Kepuasan Kerja 3. Etos Kerja berpengaruh positif dan tidak signifikan terhadap Prestasi Kerja 4. Disiplin Kerja berpengaruh positif dan signifikan terhadap Prestasi Kerja 5.Kepuasan Kerja berpengaruh positif dan signifikan terhadap Prestasi Kerja. 6. Etos kerja berpengaruh positif dan signifikan terhadap prestasi kerja melalui kepuasan kerja 7. Disiplin kerja berpengaruh positif dan signifikan terhadap prestasi kerja melalui kepuasan kerja.
\end{abstract}

Keyword: Prestasi Kerja,Kepuasan Kerja Etos Kerja, Disiplin Kerja.

\section{PENDAHULUAN}

\section{Latar Belakang Masalah}

Perkembangan kompetisi saat ini bersifat global yang ditandai dengan adanya perubahan-perubahan kondisi ekonomi yang menyebabkan banyak perusahaan melakukan restrukrisasi. Hal inilah yang kemudian mendorong terjadinya perubahan. Sumber daya manusia menjadi salah satu elemen penting dalam perubahan kondisi ekonomi tersebut, karena sumber daya manusia masih menjadi sorotan bagi perusahaan untuk tetap bertahan di era globalisasi. Sumber daya manusia memiliki kendali yang dapat menentukan keberlangsungan suatu perusahaan.

Dalam persaingan global saat ini dunia kerja sangat membutuhkan orang yang bisa berfikir untuk maju, cerdas, inovatif, dan mampu berkarya dengan semangat tinggi dalam menghadapi kemajuan zaman. Keberadaan sumber daya manusia dalam perusahaan menjadi ujung tombak perusahaan agar dapat mencapai tujuan yang telah direncanakan atau ditetapkan perusahaan.

Prestasi kerja mencerminkan keberhasilan atau kegagalan dalam aktivitas manajemen 
sumber daya manusia. maka kemungkinan aktivitas manajemen sumber daya manusia tersebut harus ditinjau ulang dengan melakukan penilaian terhadap prestasi kerja. Kepuasan kerja banyak yang tidak tercapai pada karyawan di sebuah perusahaan. Tidak jarang para pemimpin tidak mengetahui faktor-faktor penyebab ketidakpuasan sehingga karyawan merasa tidak puas dalam bekerja. Banyak perusahaan mengalami masalah pada kepuasaan karyawannya mulai dari insetif yang kurang, tempat kerja yang kurang nyaman hingga masalah kenaikan jabatan karyawan apabila dibiarkan maka akan terjadi tingkat turnover yang sangat tinggi.

Dalam era globalisasi ini, setiap perusahaan berusaha meningkatkan serta mengembangkan perusahaan dengan mengadakan berbagai cara yang tersusun dalam program untuk meningkatkan kinerja para karyawan. Banyak faktor yang terkait dalam perbaikan kinerja perusahaan. Diantaranya adalah pihak perusahaan kurang menerapkan sistem promosi jabatan dengan benar. Selain itu kemungkinan perusahaan tidak memperhatikan kesejahteraan karyawannya, sehingga karyawan bekerja tidak sepenuh hati yang pada akhirnya akan menurunkan tingkat kinerja. Promosi jabatan merupakan salah satu faktor yang perlu dipertimbangkan untuk dapat meningkatkan prestasi kerja karyawan sehingga karyawan bisa bekerja mencapai target perusahaan, yang akhirnya akan memampukan perusahaan mampu bersaing dengan perusahaan lainnya. Secara sederhana dapat dikatakan bahwa faktor-faktor diatas adalah hal-hal yang mempengaruhi kepuasan kerja. Karyawan yang merasa puas atau cocok dengan pekerjaanya, akan selalu bekerja dengan optimal sehingga prestasi kerjanya meningkat. Sementara itu ada yang menyatakan bahwa justru dengan prestasi kerja yang tinggi, maka kepuasan kerja karyawan secara tidak langsung akan meningkat. Menurut Gibson seperti yang dikutif dalam bukunya Wibowo, secara jelas menggambarkan adanya hubungan timbal balik antara kinerja dan kepuasan kerja. Disatu sisi dikatakan kepuasan kerja menyebabkan peningkatan kinerja sehingga pekerja yang puas akan lebih produktif. Disisi lain dapat pula terjadi kepuasan kerja disebabkan oleh adanya kinerja atau prestasi kerja sehingga pekerja yang lebih produktif akan mendapatkan kepuasan.(Nasrih, 2016).

\section{Rumusan Masalah}

Berdasarkan latar belakang diatas, maka muncul pokok permasalahan sebagai berikut :

1. Bagaimana etos kerja berpengaruh terhadap kepuasan kerja

2. Bagaimana disiplin kerja berpengaruh terhadap kepuasan

3. Bagaimana etos kerja berpengaruh terhadap prestasi kerja

4. Bagaimana disiplin kerja berpengaruh terhadap prestasi kerja

5. Bagaimana prestasi kerja berpengaruh terhadap kepuasan kerja

6. Bagaimana etos kerja berpengaruh terhadap prestasi kerja melalui kepuasan kerja

7. Bagaimana disiplin kerja berpengaruh terhadap prestasi kerja melalui kepuasan kerja

\section{KAJIAN PUSTAKA}




\section{Prestasi Kerja (Y1)}

Prestasi kerja adalah suatu metode bagi manajemen untuk membuat suatu analisa yang adil dan jujur tentang nilai karyawan bagi organisasi. Kinerja (performance) diistilahkan sebagai prestasi kerja yaitu proses melalui evaluasi organisasi atau menilai prestasi kerja karyawan Prestasi kerja didefinisikan sebagai Performance is defined as the record of outcome produced on a specified job function or activity during a specifiedtimeperiod (Prestasi kerja didefinisikan sebagai catatan dari hasil yang diperoleh melalui fungsi-fungsi pekerjaan tertentu) (Yatipai \& Kaparang, 2015)

Prestasi kerja merupakan perwujudan dari hasil kerja seseorang yang akan menentukan perkembangan kariernya pada masa yang akan datang. Prestasi kerja menurut (M. Hasibuan, 2008) adalah suatu hasil kerja yang dicapai seseorang dalam melaksanakan tugas-tugas yang dibebankan kepadanya yang didasarkan atas kecakapan dan kesungguhan serta waktu. Berdasarkan uraian di atas dapat diketahui bahwa pengertian prestasi kerja karyawan yaitu kemampuan seseorang untuk menyelesaikan pekerjaan yang diberikan kepadanya denggan kesungguhan dan ketetapan waktu serta pengalaman yang ia miliki sehingga dapat menghasilkan sesuatu yang positif yang dapat menentukan perkembangan kariernya di masa yang akan datang (Rulianti, 2020).

Hasibuan (R.Hasibuan, 2018), menjelaskan Prestasi kerja adalah suatu hasil kerja yang dicapai seseorang dalam melaksanakan tugas-tugas yang dibebankan kepadanya yang didasarkan atas kecakapan dan kesungguhan serta waktu. Menurut Mangkunegara (2005:91) prestasi kerja karyawan berarti prestasi atau kontribusi yang diberikan oleh karyawan dalam melaksanakan tugas dan tanggung jawab serta fungsinya sebagai karyawan di perusahaan. Dari pengertian di atas dapat disimpulkan bahwa prestasi kerja dapat diartikan sebagai hasil kerja secara kualitas dan kuantitas yang dicapai oleh seorang karyawan selama periode waktu tertentu dalam melaksanakan tugas kerjanya sesuai dengan tanggung jawab yang diberikan kepadanya (Effendi, Maya Syafriana, 2018).

\section{Faktor - Faktor yang mempengaruhi Prestasi Kerja}

faktor-faktor yang mempengaruhi yaitu faktor individu dan faktor lingkungan. Faktor individu yang dimaksud adalah :

1. Usaha (effort) yang menunjukkan sejumlah sinergi fisik dan mental yang digunakandalam menyelenggarakan tugas.

2. Abilities, yaitu sifat-sifat personal yang diperlukan untuk melaksanakan suatu tugas.

3. Role/Task Perception yaitu segala prilaku dan aktivitas yang dirasa perlu oleh individu untuk menyelesaikan suatu pekerjaan.

Adapun faktor-faktor lingkungan yang mempengaruhi prestasi kerja adalah :

1. Kondisi fisik, dengan memiliki kondisi fisik yang baik maka karyawan dapat bekerja dengan baik dan meningkatkan prestasi kerjanya dengan baik pula. 
2. Peralatan, adanya pelaratan yang lengkap maka ini akan mempengaruhi hasil kerja setiap karyawannya.

3. Waktu, jika karyawan mampu bekerja dan menyelesaikan tugas tepat pada waktunya maka ini juga akan mempengaruhi hasil kerjanya dan dapat mencapai target yang telah ditetapkan.

4. Material, tersedianya material sesuai dengan yang dibutuhkan maka hal ini juga menjadi salah satu pendukung berhasilnya sebuah perusahaan.

5. Pendidikan, adanya tingkat pendidikan yang baik maka ini akan mempengaruhi hasil kerja setiap karyawan untuk mendapatkan prestasi yang baik.

6. Supervisi, dengan pengawasan supervisi yang teliti bahwasannya akan tau mana karyawan yang berprestasi dan tidak berprestasi.

7. Desain organisasi, hal ini akan mempengaruhi karyawan untuk bekerja lebih giat lagi karena dengan adanya desain organisasi ini tentunya setiap organisasi memiliki reward yang akan diberikan kepada karyawan yang berprestasi.

8. Pelatihan, adanya pelatihan kerja yang disediakan oleh perusahaan setelah itu diberikan reward yang berupa promosi jabatan, maka ini akan berdampak positif bagi karyawan yang memiliki prestasi kerja yang baik, dan karyawan yang tidak berprestasi tentunya akan berlomba-lomba untuk memperbaiki kesalahan demi mendapatkan sebuah reward tersebut.

9. Keberuntungan, setiap karyawan yang berprestasi tentunya memiliki keberuntungan yang baik, maka hal ini menjadi sebuah motivasi bagi setiap karyawan yang malas untuk bekerja agar meningkatkan prestasi yang baik pula.

Penilaian prestasi kerja dapat digunakan untuk menentukkan tindakan yang tepat terhadap para karyawan. (Handoko, 2012) mengungkapkan salah satu tindakan yang dapat diambil adalah menentukkan pemberian kompensasi dan penempatan seperti promosi jabatan kepada karyawan yang berprestasi atau karyawan dengan kinerja yang meningkat dari sebelumnya. Menurut (pangabean, S, 2004) kompensasi merupakan setiap bentuk penghargaan yang diberikan kepada karyawan sebagai balas jasa atas kontribusi yang mereka berikan kepada organisasi. Sehingga apabila kompensasi didasarkan pada penilaian prestasi kerja dan penilaian tersebut dianggap objektif dan adil bagi karyawan, maka kompensasi dapat meningkatkan motivasi karyawan.(Pribadi \& Harjanti, 2014).

Prestasi kerja adalah hasil kerja seseorang karyawan selama periode tertentu dibandingkan dengan berbagai kemungkinan misalnya standard, target/sasaran atau kriteria yang telah ditentukan terlebih dahulu dan disepakati bersama. Menurut Bernadin dan Rusel dalam Sutrisno, prestasi adalah catatan hasil-hasil yang diperoleh dari fungsi-fungsi pekerjaan tertentu atau kegiatan tertentu selama kurun waktu tertentu .Prestasi kerja seorang karyawan pada dasarnya adalah hasil kerja seorang karyawan selama periode tertentu dibandingkan dengan berbagai kemungkinan, misalnya standar, target atau kriteria yang telah ditentukan telebih dahulu dan telah disepakati bersama(Soeprianto, n.d.). Prestasi kerja adalah hasil kerja secara kuantitas dan kualitas yang dicapai seseorang karyawan dalam melaksanakan tugasnya sesuai dengan tanggung jawab yang diberikan kepadanya (Mangkunegara, 2006:9). 
Sedangkan penilaian pelaksanaan pekerjaan atau penilaian prestasi kerja (appraisal of performance) adalah suatu sistem yang digunakan untuk menilai dan mengetahui apakah seorang karyawan telah melaksanakan pekerjaannya masingmasing secara keseluruhan. Dalam hal ini, pelaksanaan pekerjaan secara keseluruhan bukan berarti hanya dilihat/dinilai hasil fisiknya saja tetapi meliputi berbagai hal seperti kuantitas kerja, kualitas kerja, displin, kerjasama, tanggung jawab, kesetiaan, kejujuran, dan loyalitas (Soeprianto, n.d.). Menurut Sikula dalam (R.Hasibuan, 2018)Penilaian prestasi kerja adalah evaluasi yang sistematis terhadap pekerjaan yang telah dilakukan oleh karyawan dan ditujukan untuk pengembangan. (Yamanie \& Y, 2016).

\section{Kepuasan Kerja (Y2)}

(Judge, 2015) kepuasan kerja adalah "sikap umum terhadap pekerjaan seseorang yang menunjukkan perbedaan antara jumlah penghargaan yang diterima pekerja dan jumlah yang mereka yakini seharusnya mereka terima". Kepuasan kerja merupakan respon afektif atau emosional terhadap berbagai segi atau aspek pekerjaan seseorang sehingga kepuasan kerja bukan merupakan konsep tunggal. Seseorang dapat relatif puas dengan salah satu aspek pekerjaan dan tidak puas dengan satu atau lebih aspek lainnya Sedangkan menurut(R.Hasibuan, 2018) kepuasan kerja karyawan dipengaruhi oleh faktor-faktor:

1. Balas jasa yang layak dan adil

2. Penempatan yang tepat dan sesuai dengan keahlian

3. Berat ringannya pekerjaan

4. Suasana dan lingkungan pekerjaan

5. Peralatan yang menunjang pelaksanaan pekerjaan

6. Sikap pemimpin dalam kepemimpinannya

7. Sifat pekerjaan monoton atau tidak Perusahaan keluarga adalah sebuah

Kepuasan Kerja merupakan sikap (positif) tenaga kerja terhadap pekerjaannya, yang timbul berdasarkan penilaian terhadap situasi kerja. Penilaian tersebut dapat dilakukan terhadap salah satu pekerjaannya, penilaian dilakukan sebagai rasa menghargai dalam mencapai salah satu nilai-nilai penting dalam pekerjaan. Karyawan yang puas lebih menyukai situasi kerjanya daripada tidak menyukainya. Perasaan-perasaan yang berhubungan dengan kepuasan dan ketidakpuasan kerja cenderung mencerminkan penaksiran dari tenaga kerja tentang pengalamanpengalaman kerja pada waktu sekarang dan lampau daripada harapanharapan untuk masa depan. Sehingga dapat disimpulkan bahwa terdapat dua unsur penting dalam kepuasan kerja, yaitu nilai-nilai pekerjaan dan kebutuhan-Kebutuhan dasar.(Judge, 2015).

(Hamali, 2016, p. 16) setiap orang yang bekerja mengharapkan dapat memperoleh kepuasan Kepuasan pada Supervisi. dari tempatnya bekerja. Kepuasan kerja akan mempengangaruhi 
produktivitas yang sangat diharapkan oleh seorang manajer, sehingga seorang manajer perlu memahami apa yang harus dilakukan untuk menciptakan kepuasan kerja karyawanya. Pengertian kepuasan kerja yang dikemukakan oleh para ahli manajemen adalah sebagai berikut:

1. Robbins dan Coulter yang diterjemahkan oleh (Edison, Emron. Yohny anwar, 2016)menyebutkan bahwa, "Job satisfaction refens to a person' general attitude toward his or job” (kepuasan kerja merupakan sikap umum seseorang terhadap pekerjaanya).

2. Green dan Baron yang diterjemahkan oleh (Hamali, 2016, p. 200) mendeskripsikan kepuasan kerja sebagai sikap positif atau negatif yang dilakukan individual terhadap pekerjaanya.

3. Gibson yang diterjemahkan oleh (Hamali, 2016, p. 201) menyatakan bahwa kepuasan kerja sebagai sikap yang dimiliki pekerja tentang pekerjaan yang dilakukan.

4. Sutrisno (Hamali, 2016, p. 202) kepuasan kerja mengandung arti sebagai berikut menyatakan bahwa kepuasan kerja adalah suatu sikap karyawan terhadap pekerjaan yang berhubungan dengan situasi kerja, kerjasama antar karyawan, imbalan yang diterima dalam bekerja, dan hal-hal lain yang menyangkut faktor fisik dan psikologis. Sikap terhadap pekerjaan ini merupakan hasil dari sejumlah sikap khusus individu terhadap factor-faktor pekerjaan, penyesuaian diri individu, dan hubungan sosial individu diluar pekerjaan sehingga menimbulkan sikap umum individu terhadap pekerjaan yang dihadapinya

\section{Indikator-indikator Kepuasan Kerja}

Indikator-indikator Kepuasan Kerja(Luthans, 2006, pp. 244-245) mengungkapkan terdapat sejumlah indikator-indikator kepuasan kerja, yaitu:

a. Pekerjaan itu sendiri Kepuasan pekerjaan itu sendiri merupakan sumber utama kepuasan.

b. Gaji Upah dan gaji dikenal menjadi signifikan, tetapi kompleks secara kognitif dan merupakan faktor multidimensi dalam kepuasan kerja Jurnal Administrasi Bisnis (JAB)|Vol. 34 No. 1 Mei 2016| administrasibisnis.studentjournal.ub.ac.id 40

c. Promosi Kesempatan promosi sepertinya memiliki pengaruh berbeda pada kepuasan kerja karena promosi memiliki sejumlah bentuk yang berbeda dan memiliki berbagai penghargaan.

d. Pengawasan Pengawasan merupakan sumber penting lain dari kepuasan kerja. Terdapat dua dimensi gaya pengawasan yang memengaruhi kepuasan kerja. Yang pertama adalah berpusat pada karyawan dan dimensi yang lain adalah partisipasi atau pengaruh, seperti diilustrasikan oleh manajer yang memungkinkan orang untuk berpartisipasi dalam pengambilan keputusan.

e. Rekan Kerja rekan kerja atau anggota tim yang kooperatif merupakan sumber kepuasan kerja yang paling sederhana pada karyawan secara individu. Kelompok kerja, terutama tim yang kuat bertindak sebagai sumber dukungan, kenyamanan, nasihat, dan bantuan pada anggota individu. 
f. Kondisi Kerja Efek lingkungan kerja pada kepuasan kerja sama halnya dengan efek kelompok kerja. Jika segalanya berjalan baik, tidak ada masalah kepuasan kerja. Komitmen Organisasional.

Kinerja Karyawansudah banyak di teliti oleh peneliti sebelumnya diantaranya adalah: (Ali et al., 2016), (Prihartono \& Ali, 2020), (Harini et al., 2020), (Riyanto, Pratomo, et al., 2017), (Brata, Husani, Hapzi, 2017), (Agussalim, Kristin, et al., 2016), (Desfiandi et al., 2017), (Sulaeman et al., 2019), (Djojo \& Ali, 2012), (Riyanto, Sutrisno, et al., 2017), (Prayetno \& Ali, 2017), (Ridwan et al., 2020), (Djoko Setyo Widodo, P. Eddy Sanusi Silitonga, 2017), (Agussalim, Ayu Rezkiana Putri, et al., 2016).

\section{Etos Kerja (X1)}

Etos Kerja adalah seperangkat perilaku positif yang berakar pada keyakinan fundamental yang disertai komitmen total pada paradigma kerja yang integral. Menurutnya, jika seseorang, suatu organisasi, atau suatu komunitas menganut paradigma kerja, mempercayai, dan berkomitmen pada paradigma kerja tersebut, semua itu akan melahirkan sikap dan perilaku kerja mereka yang khas. Itulah yang akan menjadi Etos Kerja dan budaya.(Arsad, 2017b).

Menurut(Lie \& Wijaya, 2017) menyatakan bahwa Etos Kerja merupakan seperangkat pemahaman dan keyakinan terhadap nilai-nilai yang secara mendasar mempengaruhi kehidupan, menajadi prinsip-prinsip pergerakan dan cara berekspresi yang khas pada sekelompok orang dengan budaya serta keyakinan yang sama.

Menurut (H. A. Niazi and U. B. Luhur,2015)]Etos kerja adalah totalitas kepribadian dirinya serta cara mengekspresikan, memandang, meyakini, dan memberikan makna pada suatu, yang mendorong dirinya, untuk bertindak dan meraih amal yang optimal. Karyawan yang memiliki etos kerja yang baik akan berusaha menunjukan suatu sikap, watak serta keyakinan dalam melaksanakan suatu pekerjaan dengan bertindak dan bekerja secara optimal.

\section{Indikator Etos Kerja}

Adapun indikator - indikator didalam etos kerja (A. R. Saleh and H. Utomo,2015) yaitu:

1. Penuh tanggung jawab

2. Semangat kerja yang tinggi

3. Berdisiplin

4. Tekun dan serius

5. Menjaga martabat dan kehormatan.

\section{Disiplin Kerja (X2)}

Disiplin merupakan fungsi operatif manajemen sumber daya manusia yang sangat penting karena semakin baik disiplin karyawan, semakin tinggi produktivitas kerja yang dapat dicapai perusahaan. Disiplin karyawan pada suatu perusahaan merupakan masalah yang perlu diperhatikan, karena masalah ini dapat mengakibatkan maju mundurnya perusahaan. Perusahaan tidak akan mengalami kemajuan dan perkembangan 
bila disiplin karyawan tidak diterapkan, sehingga dapat mengakibatkan kehancuran bagi perusahaan yang bersangkutan.Adapun pengertian tentang masalah disiplin yang sebenarnya maka berikut ini penulis akan mengetengahkan beberapa teori atau pendapat para ahli, antara lain sebagai berikut:

Menurut (M. S. P. Hasibuan, 2010, p. 194) kedisplinan adalah kesadaran seseorang menaati semua peraturan perusahaan dan norma sosial yang berlaku. Kesadaran adalah sikap seseorang yang secara sukarela mentaati semua peraturan dan sadar akan tugas dan tanggung jawabnya. Kesediaan adalah sikap, tingkah laku dan perbuatan seseorang yang sesuai dengan peraturan perusahaan baik yang tertulis maupun yang tidak tertulis.

Menurut (Sedarmayanti, 2010, p. 10) kedisplinan merupakan salah satu fungsi manajemen sumber daya manusia dan kunci erwujudnya tugas, tanpa kedisiplinan akan sulit mewujudkan tujuan yang maksimal.

\section{Indikator Disiplin Kerja}

Menurut (Sekartini, 2016) indikator-indikator disiplin kerja yaitu :

1) Kehadiran.

Hal ini menjadi indikator yang mendasar untuk mengukur kedisiplinan dan biasanya karyawan yang memiliki disiplin kerja rendah terbiasa untuk terlambat dalam bekerja.

2) Ketaatan terhadap peraturan kerja.

Karyawan yang taat pada peraturan kerja tidak akan melalikan prosedur kerja dan akan selalu mengikuti pedoman kerja yang ditetapkan oleh perusahaan.

3) Ketaatan pada standar kerja.

Hal ini dapat dilihat melalui besarnya tanggung jawab karyawan terhadap tugas yang diamanahkan kepadanya.

4) Tingkat kewaspadaan tinggi

Karyawan memiliki kewaspadaan tinggi akan selalu berhati-hati, penuh perhitungan dan ketelitian dalam bekerja, serta selalu menggunakan sesuatu efektif dan efisien.

5) Bekerja etis.

Beberapa karyawan mungkin melakukan tindakan yang tidak sopan ke pelanggan atau terlibat dalam tin-dakan yang tidak pantas. Hal ini merupakan salah satu bentuk tindakan indisipliner, se-hingga bekerja etis sebagai salah satu wujud dari disiplin kerja karyawan.

\section{METODE PENULISAN}

Metode penulisan artikel ilmiah ini adalah dengan metode kualitatif dan studi literature atau Library Research.Mengkaji Buku-buku literature sesuai dengan teori yang di bahas khusunya di lingkup Manajemen Sumberdaya Manusia (MSDM).Disamping itu menganalisis artikel-artikel ilmiah yang bereputasi dan juga artikel ilmiah dari jurnal yang belum bereputasi.Semua artikel ilmiah yang di citasi bersumber dari Mendeley dan Scholar Google. 
Dalam penelitian kualitatif, kajian pustaka harus digunakan secara konsisten dengan asumsi-asumsi metodologis. Artinya harus digunakan secara induktif sehingga tidak mengarahkan pertanyaan-pertanyaan yang diajukan oleh peneliti. Salah satu alasan utama untuk melakukan penelitian kualitatif yaitu bahwa penelitian tersebut bersifat eksploratif,(Ali \& Limakrisna, 2013).

Selanjutnya dibahas secara mendalam pada bagian yang berjudul" Pustaka Terkait" (Related Literature) atau Kajian pustaka("Review of Literature"), sebagai dasar perumusan hipotesis dan selanjutnya akan menjadi dasar untuk melakukan perbandingan dengan hasil atau temuan-temuan yang terungkap dalam penelitian, (Ali \& Limakrisna, 2013).

\section{PEMBAHASAN}

Berdasarkan rumusan masalah dan kajian literature review, maka pembahsan artikel ini adalah sebagai berikut:

\section{Etos kerja berpengaruh terhadap kepuasan kerja}

Pengaruh Etos Kerja, Kepemimpinan, Dan Budaya Organisasi Terhadap Kepuasan Kerja Serta Dampaknya terhadap Kinerja Karyawan (Studi Kasus Pada Badan Penanggulangan Bencana Daerah Provinsi Nusa Tenggara Barat) Hasil analisis dan pembahasan diperoleh Bahwa penelitian ini menunjukkan Etos kerja, kepemimpinan dan budaya organisasi secara bersama berpengaruh positif dan signifikan terhadap kepuasan kerja.(Simanjuntak, Putra Arif, 2020) Pengaruh Etos Kerja, Kepuasan Kerja, Sikap Kerja Dan Motivasi Kerja Terhadap Kinerja Pegawai Pada Kantor Pelayanan Pajak Pratama Medan Polonia, Hasil penelitian ini bahwa baik secara parsial maupun secara simultan berpengaruh positif dan signifikan antara etos kerja terhadap kinerja pegawai. (Usoh et al., 2020) Pengaruh Etos Kerja, Kepuasan Kerja Dan Budaya Organisasi Terhadap Kinerja Karyawan Pada Tasik Ria Resort Hasil penelitian ini menunjukkan bahwa: (1) Etos kerja, kepuasan kerja dan budaya organisasi berpengaruh positif secara parsial terhadap kinerja karyawan Tasik Ria Resort; dan (2) Etos kerja, kepuasan kerja dan budaya organisasi berpengaruh secara simultan terhadap kinerja karyawa Tasik Ria Resort. Pihak manajemen dan para karyawan dari Tasik Ria Resort harus mempertahankan dan meningkatkan etos kerja, kepuasan kerja dan budaya organisasi organisasi di resort ini sehingga kinerja karyawan tetap baik dan harus memperhatikan faktorfaktor lain yang mempengaruhi kinerja karyawan.

\section{Disiplin kerja berpengaruh terhadap kepuasan}

(Sajangbati, 2013) Pengaruh motivasi, disiplin kerja,dan kepuasan kerja terhadap kinerja pegawai Pt. Pos Indonesia (Persero) Cabang Bitung Secara bersama variabel motivasi, disiplin kerja dan kepuasan kerja berpengaruh secara signifikan terhadap kinerja pegawai.(Arsad, 2017a) Pengaruh etos kerja dan disiplin kerja terhadap prestasi kerja di kantor kecamatan anggana kabupaten kutai kartanegara. (sri rahayu, se., 2018) Pengaruh motivasi dan disiplin terhadap prestasi kerja karyawan di PT. Langkat Nusantara Kepong Kabupaten Langkat. Hasil analisis dan pembahasan diperoleh Bahwa penelitian ini menunjukkan Motivasi dan disiplin secara srimultan berpengaruh positif dan signifikan 
terhadap prestasi kerja. (Alamsyah Yunus,2013)Pengaruh Disiplin Kerja, Motivasi, Kepemimpinan Terhadap Kepuasan Kerja Karyawan Studi Pada Pt. Bumi Barito Utama Cabang Banjarmasin Hasil penelitian secara parsial menunjukkan bahwa disiplin kerja berpengaruh positif dan signifi kan terhadap kepuasan kerja, variabel motivasi berpengaruh positif dan signifi kan terhadap kepuasan kerja dan variabel kepemimpinan berpengaruh positif dan signifi kan terhadap kepuasan kerja. Hasil penelitian secara simultan menunjukkan bahwa variabel disiplin kerja, motivasi dan kepemimpinan berpengaruh positif dan signifi kan terhadap kepuasan kerja. Dari tiga variabel bebas yang diteliti variabel yang mempunyai pengaruh terbesar/dominan adalah variabel motivasi dengan nilai koefi sien regresi sebesar 0,464 atau 46,4 \% terhadap kepuasan kerja dibandingkan dengan kedua variabel independen lainnya.

\section{Etos kerja berpengaruh terhadap prestasi kerja}

Arsad (2017) Pengaruh etos kerja dan disiplin kerja terhadap prestasi kerja di kantor kecamatan anggana kabupaten kutai kartanegara Hasil analisis dan pembahasan diperoleh Bahwa penelitian ini menunjukkan etos kerja dan lingkungan kerja secara bersama-sama berpengaruh positif dan signifikan terhadap prestasi kerja (Agussalim, Kristin, et al., 2016) Analysis Work Discipline and Work Spirit to Achievement Employees Pt. Japfa Comfeed Indonesia Tbk. Wood Planting Hasil analisis dan pembahasan diperoleh Bahwa penelitian ini menunjukkan.

Secara tidak langsung terdapat pengaruh yang signifikan variabel disiplin kerja terhadap prestasi kerja. (Ika Puspita Sari,2009) Hubungan Antara Etos Kerja Dengan Prestasi Kerja Karyawan Industri Batik Semarangan Di Kota Semarang Hasil perhitungan Analisis Korelasi diperoleh korelasi antara etos kerja dengan prestasi kerja 0,664 dengan probabilitas 0,000 dengan $r$ tabel product moment dengan banyak responden 31 dan tingkat kepercayaan atau $\alpha=5(\mathrm{r}(5 \%: 31))$ adalah 0,355. Karena probabilitas $<0,005$ atau harga korelasinya $(0,664)>0,355$ maka koefisien korelasi tersebut signifikan/bermakna ada hubungan yang berarti antara etos kerja dengan prestasi kerja. Besar kontribusi etos kerja terhadap prestasi kerja $=44,1 \%$ Simpulan dari penelitian ini adalah 1)Ada hubungan antara etos kerja dengan prestasi kerja (hasil kerja maupun produktivitas kerja) karyawan industri batik Semarangan di Kota Semarang.2)Besar hubungan antara etos kerja dengan prestasi kerja karyawan industri batik Semarangan di Kota Semarang sebesar 0,664 dan mempunyai kontribusi sebesar 44,1\%.Saran yang dapat diberikan adalah sebagai berikut. 1)Untuk meningkatkan prestasi kerja karyawan (pembatik), pimpinan atau pengusaha batik perlu mengupayakan:a)meningkatkan etos kerja para karyawan (pembatik) Berdasarkan penelitian, indikator hemat mempunyai skor 79,03\% yang lebih kecil dibandingkan dengan indikator lainnya, oleh karena itu disarankan kepada karyawan untuk melakukan penghematan terhadap bahan pembatikan dan melakukan penghematan waktu. b) pemberian bonus kepada pembatik yang memiliki prestasi kerja baik sehingga karyawan termotivasi untuk meningkatkan prestasi kerjanya. 


\section{Disiplin kerja berpengaruh terhadap prestasi kerja}

Pengaruh disiplin kerja, komitmen organisasi dan kompensasi terhadap prestasi kerja karyawan PT. Garuda Area Jaya Batam Hasil analisis dan pembahasan diperoleh Bahwa penelitian ini menunjukkan disiplin kerja, komitmen organisasi dan kompensasi secara srimultan berpengaruh positif dan signifikan terhadap prestasi kerja karyawan. (Rahmi \& Aziz, 2017) Tanjung (2015) Pengaruh disiplin kerja dan motivasi kerja terhadap prestasi kerja pegawai pada dinas social dan tenaga kerja kota medan Hasil analisis dan pembahasan diperoleh Bahwa penelitian ini menunjukkan disiplin kerja dan motivasi kerja berpengaruh positif dan signifikan terhadap prestasi kerja pegawai. Rahmi \& Aziz (2017) Pengaruh disiplin kerja, pelatihan kerja dan kemampuan kerja terhadap prestasi kerja biro umum kantor gubernur kantor gubernur provinsi aceh $\backslash$ Saputra \& Hendri (2016) Pengaruh disiplin kerja terhadap prestasi kerja dengan kepuasan kerja sebagai variable intervening pada stasiun TVRI sumatera selatan. Hasil analisis dan pembahasan diperoleh Bahwa penelitian ini menunjukkan Secara tidak langsung terdapat pengaruh yang signifikan variabel disiplin kerja terhadap prestasi kerja melalui kepuasan kerja. Koefisien jalur pengaruh tidak langsung diperoleh sebesar 0,042, sedangkan besarnya pengaruh langsung yaitu sebesar 0,383. (Ahmad Jais,2017) Pengaruh Disiplin Kerja Dan Lingkungan Kerja Terhadap Prestasi Kerja Pegawai Pada Rumah Sakit Umum Daerah H. Andi Sulthan Daeng Radja Kabupaten Bulukumba Hasil penelitian ini menunjukkan bahwa: 1) Disiplin kerja dan lingkungan kerja berpengaruh secara simultan terhadap prestasi kerja pegawai. 2) Disiplin kerja berpengaruh secara positif dan signifikan terhadap prestasi kerja pegawai. 3) Lingkungan kerja berpengaruh positif dan signifikan terhadap prestasi kerja pegawai. 4) secara parsial yang berpengaruh paling dominan adalah disiplin kerja. Implikasi dari penelitian ini adanya pemerhatian kebersihan ruang kerja sehingga tugas yang diberikan pegawai dikerjakan dengan baik dan diharapkan adanya peningkatan kedisiplinan dalam organisasi karena dengan ditingkatkannya disiplin pegawai akan lebih mengetahui kejelasan dan kemampuan dalam menjalankan suatu pekerjaan.

\section{Prestasi kerja berpengaruh terhadap kepuasan kerja}

Ningsih (2017) Pengaruh disiplin, kompensasi dan beban kerja terhadap prestasi kerja karyawan PT. mega finance cabang pekanbaru Hasil analisis dan pembahasan diperoleh Bahwa penelitian ini menunjukkan disiplin, kompensasi an beban kerja secara srimultan berpengaruh positif dan signifikan terhadap prestasi kerja karyawa. (Sekartini, 2016) Pengaruh kemampuan kerja, disiplin kerja dan motivasi kerja terhadap kepuasan kerja dan kinerja karyawan administrasi universitas warmadewa Hasil analisis dan pembahasan diperoleh Bahwa penelitian ini menunjukkan Disiplin kerja berpengaruh positif dan tidak signifikan terhadap kepuasan kerja. Atinya semakin meningkatnya disiplin kerja di masingmasing bidang tidak dapat meningkatkan kepuasan kerja karyawan Unversitas Warmadewa.

\section{Etos kerja berpengaruh terhadap prestasi kerja melalui kepuasan kerja}

(Nikita Maria Usoh,Bernhard dan Tewal.2020) Regina Saerangpengaruh Etos Kerja, Kepuasan Kerja Dan Budaya Organisasi Terhadap Kinerja Karyawan Pada Tasik Ria Resort sioner, analisis regresi berganda dengan uji asumsi klasik untuk kelayakan model; uji-F dan 
uji-t untuk pembuktian hipotesis. Hasil penelitian ini menunjukkan bahwa: (1) Etos kerja, kepuasan kerja dan budaya organisasi berpengaruh positif secara parsial terhadap kinerja karyawan Tasik Ria Resort; dan (2) Etos kerja, kepuasan kerja dan budaya organisasi berpengaruh secara simultan terhadap kinerja karyawa Tasik Ria Resort. Pihak manajemen dan para karyawan dari Tasik Ria Resort harus mempertahankan dan meningkatkan etos kerja, kepuasan kerja dan budaya organisasi organisasi di resort ini sehingga kinerja karyawan tetap baik dan harus memperhatikan faktor-faktor lain yang mempengaruhi kinerja karyawan. (Rina Milyati Yuniastuti 2011)Pengaruh Kepuasan Kerja Terhadap Prestasi Kerja Karyawan Pada Cv. Organik Agro System Di Bandar Lampung Berdasarkan hasil perhitungan diperoleh: koefisien korelasi Product Moment rxy $=0,815$, ini menunjukan bahwa Kepuasan Kerja mempunyai hubungan yang sangat kuat dan positif dengan Prestasi Kerja Karyawan; Koefisien Determinasi $=66,40 \%$, ini menunjukan bahwa Kepuasan Kerja memberikan pengaruh sebesar 66,40\% terhadap Prestasi Kerja Karyawan dan sebesar 33,60\% dipengaruhi oleh faktor lain yang tidak dibahas pada penelitian ini; dan nilai rxy atau r-hitung 0,815 > r-tabel 0,396 pada tingkat kepercayaan 95\%, maka Ho ditolak dan Ha diterima berari : Kepuasan Kerja berpengaruh signifikan terhadap Prestasi Kerja Karyawan. Dengan demikian dapat disimpulkan bahwa hipotesis penelitian yang menyatakan bahwa Kepuasan Kerja berpengaruh signifikan terhadap Prestasi Kerja Karyawan pada CV.Organik Agro System (O ASIS) dapat diterima

Prariset: Survey Faktor-Faktor yang dominan mempengarui Prestasi Kerja(Y1) dan Kepuasan Kerja (Y2).

Banyak faktor yang mempengarui Prestasi Kerja(Y1) dan Kepuasan Kerja (Y2). Dibawah ini ada 10 Faktor atau variable yang memppengarui Prestasi Kerja(Y1) dan Kepuasan Kerja (Y2) pada perusahaan jasa minsalnya industry perbankan,perhotelan,asuransi dan perusahaan jasa lainya. Rekap hasil prariset ini mengunakan skala likert 5 yaitu :

1. Tidak Berpengaruh

2. Kurang berpengaruh

3. Cukup berpengaruh

4. Berpengaruh dan

5. Sangat berpengaruh

Tabel .1.1 PraRiset

\begin{tabular}{|l|l|l|l|}
\hline & Yang Mempengarui Y & & \\
\hline 1 & A & 60 & 8 \\
\hline 2 & Etos kerja(B) & $\mathbf{9 0}$ & $\mathbf{1}$ \\
\hline 3 & C & 54 & 9 \\
\hline 4 & D & 70 & 6 \\
\hline 5 & E & 76 & 4 \\
\hline
\end{tabular}




\begin{tabular}{|l|l|l|l|}
\hline 6 & F & 80 & 3 \\
\hline 7 & Disiplin Kerja(G) & $\mathbf{8 6}$ & $\mathbf{2}$ \\
\hline 8 & H & 50 & 10 \\
\hline 9 & I & 66 & 7 \\
\hline 10 & J & 73 & 5 \\
\hline
\end{tabular}

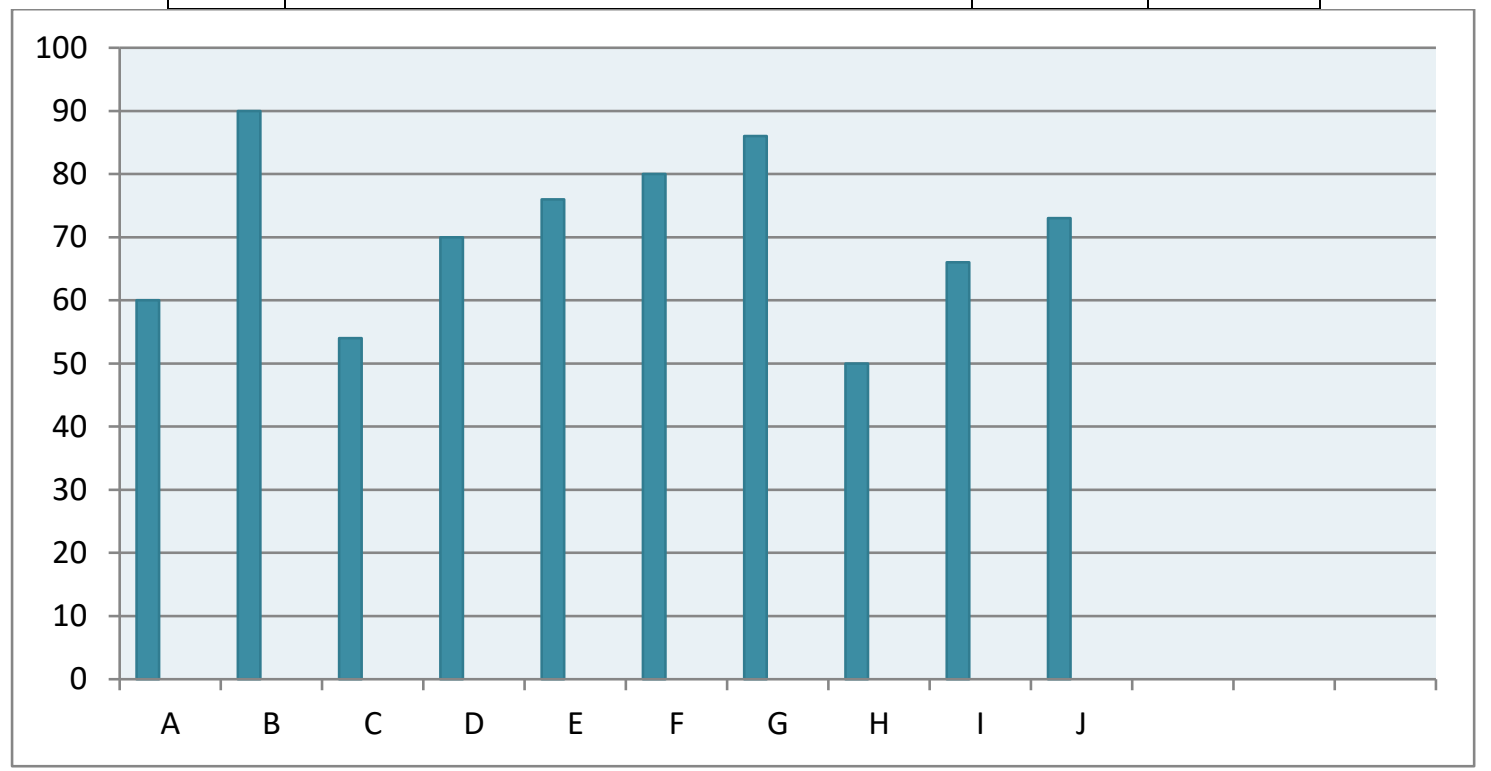

Figure 1: Grafik hasil Pra Survey

Hasil nya prariset ini bahwa 2 faktor yang dominan mempengarui Y1 dan Y2 adalah sebagai berikut :

- $\quad$ Skor tertinggi 1 = Faktor B, sebagai Etos $\operatorname{Kerja}(X 1)$

- Skor tertinggi 2 = Faktor G, sebagai Disiplin Kerja (X1)

\section{Conceptual Framework}

Berdasarkan Kajian teori dan hubungan antar variabel maka model atau Conceptual Framework artikel ini dalam rangka menbagunan hipotesis adalah sebagai berikut:

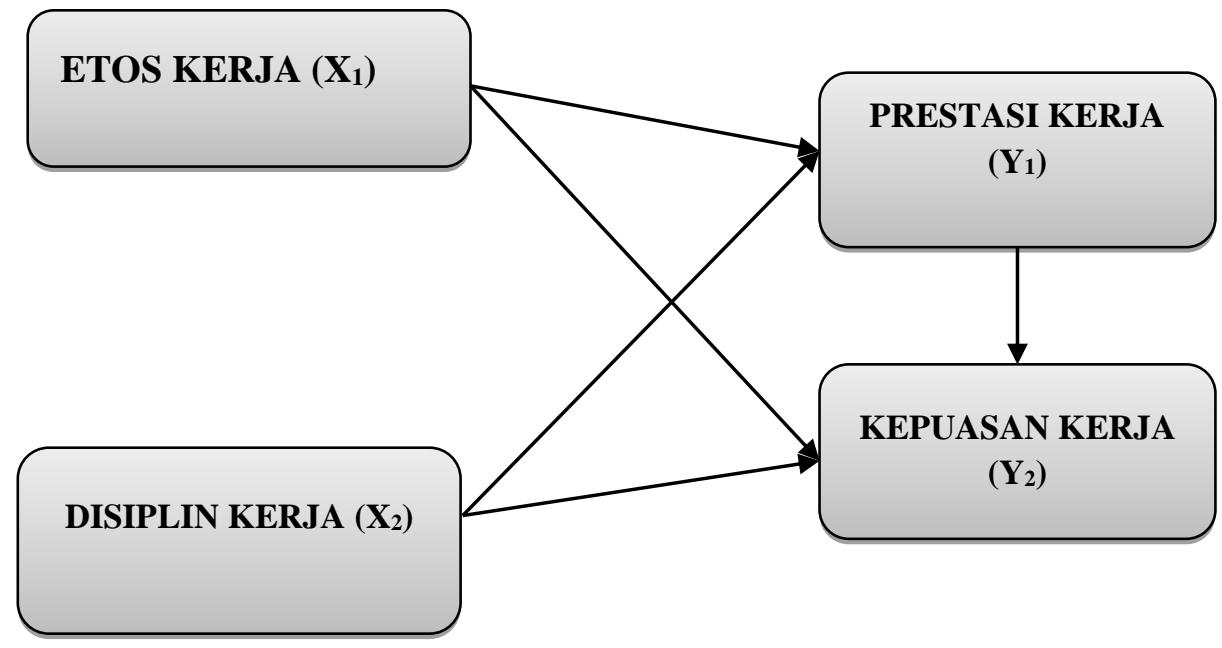

Gambar 3: Conceptual Framework 
Etos kerja (x1), dan Etos kerja (x2) berpengaruh prestasi kerja $\left(\mathrm{y}_{1}\right)$ dan kepuasan kerja $(\mathrm{y} 2)$ baik secara langsung dan tidak langsung. Selain dari variabel etos kerja (x1), dan disiplin kerja ( $x 2$ ) yang berpengaruh terhadap prestasi kerja (y1) dan kepuasan kerja (y2), masih banyak variabel lain diataranya adalah:

1) Linkungan kerja (x4): (Purba et al., 2017), (Sardjijo \& Ali, 2017);

2) Motivasi kerja (x5):(Riyanto, Sutrisno, et al., 2017), (Bastari et al., 2020), (Prayetno \& Ali, 2017), (Rivai et al., 2017), (Chauhan et al., 2019); dan

3) Budaya kerja (x6): (Harini et al., 2020), (Elmi et al., 2016).

\section{KESIMPULAN DAN SARAN \\ Kesimpulan}

1. Etos Kerja berpengaruh positif dan signifikan terhadap Kepuasan Kerja

2. Disiplin Kerja berpengaruh positif dan signifikan terhadap Kepuasan Kerja

3. Etos Kerja berpengaruh positif dan tidak signifikan terhadap Prestasi Kerja

4. Disiplin Kerja berpengaruh positif dan signifikan terhadap Prestasi Kerja

5. Kepuasan Kerja berpengaruh positif dan signifikan terhadap Prestasi Kerja

6. Kepuasan kerja memediasi Etos Kerja terhadap Prestasi Kerja

7. Kepuasan kerja tidak memediasi Disiplin Kerja terhadap Prestasi Kerja

\section{Saran}

Berdasarkan kesimpulan diatas, maka penulis akan memberikan saran-saran sebagai berikut:

a. Memberikan perhatian dan dorongan terhadap etos kerja berupa apresiasi agar karyawan lebih aktif, inovatif dan kreatif lagi dalam bekerja.

b. Lebih memprioritaskan perhatian terhadap disiplin kerja karyawan agar tetap mematuhi aturan yang trelah ditetapkan oleh perusahaan.

c. Peneliti berharap pihak perusahaan lebih peduli kondisi kerja karyawan mendukung adanya kepuasan kerja tersendiri pada karyawan. Menyediakan fasilitas yang lebih lengkap agar memudahkan karyawan untuk bekerja.

d. Memberikan motivasi kepada karyawan dan memberikan insentif tambahan kepada karyawan yang berprestasi.

e. Agar etos kerja karyawan tetap terjaga, sebaiknya perusahaan adanya kepastian kepada karyawan tentang jenjang promosi jabatan dan sehingga memacu karyawan untuk berprestasi

\section{DAFTAR RUJUKAN}

Agussalim, M., Ayu Rezkiana Putri, M., \& Ali, H. (2016). Analysis work discipline and work spirit toward performance of employees (case study tax office Pratama two Padang). International Journal of Economic Research.

Agussalim, M., Kristin, M., \& Ali, H. (2016). Role of revolving loan program community national urban self (PNPM MP) against poverty prevention in Padang. International 
Journal of Applied Business and Economic Research.

Ali, H., \& Limakrisna, N. (2013). Metodologi Penelitian : Petunjuk Praktis untuk Pemecahan Masalah Bisnis, Penyusunan Skripsi, Tesis, dan Disertasi (1st ed.). DEEPUBLISH.

Ali, H., Limakrisna, N., \& Jamaluddin, S. (2016). Model of customer satisfaction: The empirical study at Bri in Jambi. International Journal of Applied Business and Economic Research.

Arsad, M. (2017a). Pengaruh Etos Kerja dan Lingkungan Kerja Terhadap Kinerja Pegawai di Kantor Kecamatan Kabupaten Kutai Kertanegara. Pemerintah Integratif, 2-3. http://ejournal.pin.or.id/site/wpcontent/uploads/2017/01/pin_arsad_prestasi\%25(01-2017-03-03-40).pdf

Arsad, M. (2017b). Pengaruh Etos Kerja Dan Lingkungan Kerja Terhadap Prestasi Kerja Di Kantor Kecamatan Anggana Kabupaten Kutai Kartanegara. E Journal PIN: Pemerintahan Integratif, 5(1), 135-147. http://ejournal.pin.or.id/site/?p=1175

Bastari, A., -, H., \& Ali, H. (2020). DETERMINANT SERVICE PERFORMANCE THROUGH MOTIVATION ANALYSIS AND TRANSFORMATIONAL LEADERSHIP. International Journal of Psychosocial Rehabilitation. https://doi.org/10.37200/ijpr/v24i4/pr201108

Brata, Husani, Hapzi, B. H. S. A. (2017). Saudi Journal of Business and Management Studies Competitive Intelligence and Knowledge Management: An Analysis of the Literature. Saudi Journal of Business and Management Studies. https://doi.org/10.21276/sjbms

Chauhan, R., Ali, H., \& Munawar, N. A. (2019). BUILDING PERFORMANCE SERVICE THROUGH TRANSFORMATIONAL LEADERSHIP ANALYSIS, WORK STRESS AND WORK MOTIVATION (EMPIRICAL CASE STUDY IN STATIONERY DISTRIBUTOR COMPANIES). Dinasti International Journal of Education Management And Social Science. https://doi.org/10.31933/dijemss.v1i1.42

Desfiandi, A., Desfiandi, A., \& Ali, H. (2017). Composite Stock Price Index (IHSG) Macro Factor in Investment in Stock (Equity Funds). International Journal of Economics and Financial Issues.

Djojo, A., \& Ali, H. (2012). Information technology service performance and client's relationship to increase banking image and its influence on deposits customer banks loyalty (A survey of Banking in Jambi). In Archives Des Sciences.

Djoko Setyo Widodo, P. Eddy Sanusi Silitonga, \& H. A. (2017). Organizational Performance : Analysis of Transformational Leadership Style and Organizational Learning. Saudi Journal of Humanities and Social Sciences. https://doi.org/10.21276/sjhss.2017.2.3.9 
Edison, Emron. Yohny anwar, I. komariyah. (2016). Manajemen Sumber Daya Manusia. Alfabeta.

Effendi, Maya Syafriana, D. (2018). Faktor-faktor yang mempengaruhi prestasi kerja. 2(74), 64.

Elmi, F., Setyadi, A., Regiana, L., \& Ali, H. (2016). Effect of leadership style, organizational culture and emotional intelligence to learning organization: On the Human Resources Development Agency of Law and Human Rights, Ministry of Law and Human Rights. International Journal of Economic Research.

Hamali, A. Y. (2016). Pemahaman Sumber Daya Manusia. CAPS.

Handoko, T. H. (2012). Manajemen Personalia dan sumberdaya manusia (BPEF).

Harini, S., Hamidah, Luddin, M. R., \& Ali, H. (2020). Analysis supply chain management factors of lecturer's turnover phenomenon. International Journal of Supply Chain Management.

Hasibuan, M. (2008). Manajemen Dasar,Pengertian,dan Masalah.

Hasibuan, M. S. P. (2010). Manajemen Sumber Daya Manusia. PT.Bumi Aksara.

Judge, R. \&. (2015). Perilaku Organisasi (S. Empat (ed.); 16th ed.).

Lie, D., \& Wijaya, A. (2017). Pengaruh Gaya Kepemimpinan Dan Etos Kerja Terhadap Kepuasan Kerja Karyawan Pada Pt Taspen (Persero) Kc Pematangsiantar. 3(2), 1-9.

Luthans, F. (2006). Perilaku Organisasi. ANDI.

Nasrih, M. L. (2016). Analisis Hubungan Kepuasan Kerja Terhadap Prestasi Kerja Karyawan. Al-Iqtishad: Journal of Islamic Economics, 2(1). https://doi.org/10.15408/aiq.v2i1.2477

Niazi, H. A., \& Luhur, U. B. (2019). Pengaruh Etos Kerja, Kepemimpinan, Dan Budaya Organisasi Terhadap Kepuasan Kerja Serta Dampaknya terhadap Kinerja Karyawan (Studi Kasus Pada Badan Penanggulangan Bencana Daerah Provinsi Nusa Tenggara Barat). 8(1), 71-85.

pangabean, S, M. (2004). Manajemen Sumber daya manusia. Ghalia Indonesia.

Prayetno, S., \& Ali, H. (2017). Analysis of advocates organizational commitment and advocates work motivation to advocates performance and its impact on performance advocates office. International Journal of Economic Research.

Pribadi, J. A., \& Harjanti, D. (2014). Pengaruh Penilaian Prestasi Kerja Terhadap Motivasi Kerja Karyawan Dengan Kompensasi Sebagai Variabel Intervening Pada Pt. Enseval Putera Megatrading Cabang Surabaya 2. Agora, 2(1). 
Prihartono, \& Ali, H. (2020). The promises ethics and marketing concept strategy as a competitive advantage on private higher education (A survey on perception of product attributes and promotion mix in Indonesia). Talent Development and Excellence.

Purba, C. B., Arzio, \& Ali, H. (2017). The influence of compensation, working environment and organization culture on working productivity of BPJS (workers social security agency) employment staff in Rawamangun Branch. Man in India.

R.Hasibuan. (2018). No Title.

Rahmi, A., \& Aziz, A. (2017). Pengaruh Disiplin Kerja, Pelatihan Kerja Dan Kemampuan Kerja Terhadap Prestasi Kerja Pegawai Biro Umum Kantor Gubernur Provinsi Aceh. Jurnal Bisnis Administrasi, 06(02), 24-31.

Ridwan, M., Mulyani, S. R., \& Ali, H. (2020). Building behavior and performance citizenship: Perceived organizational support and competence (case study at SPMI private university in west Sumatra). International Journal of Psychosocial Rehabilitation. https://doi.org/10.37200/IJPR/V24I6/PR260195

Rivai, A., Suharto, \& Ali, H. (2017). Organizational performance analysis: Loyalty predictors are mediated by work motivation at urban village in Bekasi City. International Journal of Economic Research.

Riyanto, S., Pratomo, A., \& Ali, H. (2017). EFFECT OF COMPENSATION AND JOB INSECURITY ON EMPLOYEE ENGAGEMENT (STUDY ON EMPLOYEE OF BUSINESS COMPETITION SUPERVISORY COMMISSION SECRETARIAT). International Journal of Advanced Research. https://doi.org/10.21474/ijar01/4139

Riyanto, S., Sutrisno, A., \& Ali, H. (2017). International Review of Management and Marketing The Impact of Working Motivation and Working Environment on Employees Performance in Indonesia Stock Exchange. International Review of Management and Marketing.

Rulianti, E. (2020). Prestasi kerja : penilaian kerja karyawan dan kepuasan kerja (Studi Kasus PADA pt. Mitrapak Eramandiri Cabang Cikarang). Jurnal Ekonomi Syariah Pelita Bangsa, 5(April 2020).

Sajangbati, I. A. (2013). Motivasi, Disiplin, Dan Kepuasan Pengaruhnya Terhadap Kinerja Pegawai Pt. Pos Indonesia (Persero) Cabang Bitung. Jurnal EMBA: Jurnal Riset Ekonomi, Manajemen, Bisnis Dan Akuntansi, 1(4), 667-678. https://doi.org/10.35794/emba.v1i4.2750

Sardjijo, S., \& Ali, H. (2017). Integrating Character Building into Mathematics and Science Courses in Elementary School. International Journal of Environmental and Science Education. https://doi.org/10.1007/s10648-016-9383-1 
Sedarmayanti. (2010). Sumber Daya Manusia dan Produktivitas Kerja. CV Mandar Maju.

Sekartini, N. L. (2016). Pengaruh Kemampuan Kerja,Disiplin Kerja, Motivasi Kerja terhadap Kepuasan Kerja dan Kinerja Karyawan Administrasi Universitas Warmadewa.

JAGADHITA : Jurnal Ekonomi \& Bisnis, 3(2), 64-75.

https://doi.org/10.22225/jj.3.2.130.64-75

Simanjuntak, Putra Arif. (2020). Pengaruh Etos Kerja, Kepuasan Kerja, Sikap Kerja Dan Motivasi Kerja Terhadap Kinerja Pegawai Pada Kantor Pelayanan Pajak Pratama Medan Polonia. Manajemen Bisnis Jurnal Magister Manajemen, 2(17), 48-55.

Soeprianto, J. (n.d.). Soeprianto,J.

sri rahayu, se., M. (2018). Pengaruh Motivasi Dan Disiplin Terhadap Prestasi Kerja

Karyawan Di Pt. Langkat Nusantara Kepong Kabupaten Langkat. Jurnal Manajemen Tools, 9(1), 115-132.

Sulaeman, A. S., Waluyo, B., \& Ali, H. (2019). Making dual procurement and supply chain operations: Cases in the indonesian higher education. International Journal of Supply Chain Management.

Usoh, N. M., Tewal, B., Pengaruh, R. S., Ker, E., Kerja, P. E., Kerja, K., Budaya, D. A. N., Terhadap, O., Usoh, N. M., Tewal, B., \& Saerang, R. (2020). Pengaruh Etos Kerja, Kepuasan Kerja Dan Budaya Organisasi Terhadap Kinerja Karyawan Pada Tasik Ria Resort. Jurnal EMBA: Jurnal Riset Ekonomi, Manajemen, Bisnis Dan Akuntansi, 8(1), 2126-2136. https://doi.org/10.35794/emba.v8i1.28125

Yamanie, I. Y., \& Y, S. (2016). Pengaruh Penilaian Prestasi Kerja, Komitmen Organisasi dan Disiplin Kerja terhadap Kinerja Karyawan pada PT. Pelabuhan Indonesia IV Cabang Samarinda. Jurnal Manajemen, 8(1), 55-65.

http://journal.feb.unmul.ac.id/index.php/JURNALMANAJEMEN/article/view/1186

Yatipai, T., \& Kaparang, S. G. (2015). Pengaruh Motivasi Terhadap Prestasi Kerja Karyawan Studi Pada PT Pos Indonesia Tipe C Manado. Jurnal Administrasi Bisnis, 3(011), 1-7. 